\title{
The Timing of Fetal B Cell Hyperplasia in Diabetic Rat Pregnancy
}

\author{
M. de Gasparo and R. D. G. Milner ${ }^{1}$ \\ Ciba-Geigy, Basle, Switzerland, and 'Department of Paediatrics, University of Sheffield, Children's Hospital, Sheffield, England
}

Summary. Fetal pancreatic development was measured in terms of total organ DNA and insulin concentration (ng/ $\mu \mathrm{g}$ DNA) in the offspring of rats made mildly diabetic by intraperitoneal streptozotocin injection $(60 \mathrm{mg} / \mathrm{kg})$ on the first and second day of life. On day 20 the mean pancreatic insulin concentration of fetuses of diabetic mothers was significantly higher than that of controls (27.8 versus 20.8 $\mathrm{ng} / \mu \mathrm{g}$ DNA) but no significant difference was observed on day 18 (4.47 versus $4.68 \mathrm{ng} / \mu \mathrm{g}$ DNA), day $16(0.64$ versus $0.77 \mathrm{ng} / \mu \mathrm{g}$ DNA) or day 14 (0.04 versus $0.03 \mathrm{ng} / \mu \mathrm{g}$ DNA). No significant difference in total pancreatic DNA was observed between test and control animals on day 14, 16, 18 or 20 of gestation. It is concluded that maternal streptozotocin diabetes alters the development of the differentiated fetal $B$ cell ( 20 days) but has no effect on the protodifferentiated $\mathrm{B}$ cell (14 days), or during the period of secondary transition (16-18 days).

Key words: Rat fetus, B cell differentiation, pancreatic insulin, maternal diabetes.

The infant of a diabetic mother has B cell hyperplasia and hypertrophy, and hyperinsulinaemia [1-4]. Similar observations have been made in experimental models [5-7]. The purpose of the present study was to determine at what point in prenatal life the fetal endocrine pancreatic abnormality develops. The answer to this question has relevance to the stage of development at which the $\mathrm{B}$ cell becomes sensitive to an abnormal metabolic milieu, and conversely the period of intrauterine life in which fetal hyperinsulinaemia may cause abnormal somatic development.

\section{Materials and Methods}

Newborn rats (Tif: RAI $f$ (SPF)) of both sexes were injected IP on the first and second day of life with $60 \mathrm{mg} / \mathrm{kg}$ body weight of streptozotocin (Dr. J. Stanek, Ciba-Geigy, Basle), freshly dissolved in $5 \mathrm{mmol} / \mathrm{l}$ citrate buffer ( $\mathrm{pH} 4.5$ ). Approximately two thirds of the animals survived and when aged 8 weeks they were weighed and blood was withdrawn from the retro-orbital plexus for blood glucose (glucose GOD perid ${ }^{\circledR}$, Boehringer) and plasma insulin [8] determination. The animals were given glucose by gavage ( $3.5 \mathrm{~g} / \mathrm{kg}$ body weight) after an overnight fast, and blood was collected at 0 and $60 \mathrm{~min}$ for the determination of glucose and insulin concentrations. Rats of either sex with a morning blood glucose concentration of $<5.5 \mathrm{mmol} / 1$ after withdrawal of food overnight, and a value of $>8.3 \mathrm{mmol} / 1$ one hour after an oral glucose load, were defined as showing carbohydrate intolerance.

Female and male rats aged 12 weeks or more with proven carbohydrate intolerance were mated overnight and pregnancy was timed from the detection of sperm in a vaginal plug the next morning (day 0 ).

In control pregnancies both the mother and father had normal glucose tolerance. Pregnant rats were killed between 0800 and $1100 \mathrm{~h}$ on day $14,16,18$ or 20 of gestation and the fetal pancreases from at least five litters were pooled and frozen for DNA [9] and insulin determination. Blood was collected from the mothers for glucose determination. Pancreases from control and streptozotocin treated adult animals were collected, fixed in Bouin's solution and examined histologically by immunocytochemical staining for insulin [10]. The fractional surface area that was positive for insulin was measured morphometrically [11]. Statistical analysis of the results was performed using Student's unpaired $t$-test. Results are stated as mean \pm SEM.

\section{Results}

\section{Characterization}

of Parental Carbohydrate Intolerance

Streptozotocin treated females had a modest hyperglycaemia at 0730 to $0830 \mathrm{~h}$ but similar mean plasma insulin levels to control animals (Table 1). When these animals were fasted overnight the morn- 
ing mean blood glucose and plasma insulin levels were similar in streptozotocin injected and control animals. The degree of carbohydrate intolerance was tested by performing oral glucose tolerance tests on control and streptozotocin treated rats of both sexes and different ages (Table 2). Modest and stable glucose intolerance was demonstrated over the body weight range $150-300 \mathrm{~g}$, and was independent of body weight. The streptozotocin rats had normal mean blood glucose levels when fasting but abnormally raised levels $60 \mathrm{~min}$ after oral glucose. The mean plasma insulin level at $60 \mathrm{~min}$ was also signi-

Table 1. Mean ( \pm SEM) blood glucose and plasma insulin concentrations in control and streptozotocin treated female rats

\begin{tabular}{lll}
\hline & $\begin{array}{l}\text { Control } \\
\text { rats }(9)^{\mathrm{a}}\end{array}$ & $\begin{array}{l}\text { Streptozotocin } \\
\text { treated rats } \\
(10)\end{array}$ \\
\hline Body weight $(\mathrm{g})$ & $209 \pm 3$ & $206 \pm 6$ \\
Blood glucose at $0730 \mathrm{~h}(\mathrm{mmol} / \mathrm{l})$ & $5.0 \pm 0.1$ & $6.7 \pm 0.3^{\mathrm{b}}$ \\
Plasma insulin at $0730 \mathrm{~h}(\mathrm{ng} / \mathrm{ml})$ & $1.90 \pm 0.17$ & $2.15 \pm 0.16$ \\
Fasting blood glucose $(\mathrm{mmol} / \mathrm{l})$ & $3.5 \pm 0.1$ & $3.5 \pm 0.1$ \\
Fasting plasma insulin $(\mathrm{ng} / \mathrm{ml})$ & $0.68 \pm 0.09$ & $0.61 \pm 0.07$ \\
\hline
\end{tabular}

a Number of animals shown in parentheses

${ }^{b}$ Streptozotocin treated compared with controls: $\mathrm{p}<0.01$

${ }^{c}$ Fasting animals sampled at $0730 \mathrm{~h}$ after withdrawal of food at $1600 \mathrm{~h}$ the previous day ficantly higher in test $(1.25 \pm 0.13 \mathrm{ng} / \mathrm{ml}, \mathrm{n}=10)$ than in control animals $(0.80 \pm 0.10 \mathrm{ng} / \mathrm{ml}, \mathbf{n}=9)$ $(\mathrm{p}<0.05)$.

The diabetic rats killed on day $14,16,18$ or 20 of gestation all had mean blood glucose levels at the time of caesarean section, similar to those of control animals, confirming both the mildness and stability of the diabetic condition.

The mean pancreatic insulin content of the test animals was $33.0 \pm 1.7 \mathrm{ng} / \mathrm{g}$ wet weight $(\mathrm{n}=11) \mathrm{com}$ pared with $57.8 \pm 2.4 \mathrm{ng} / \mathrm{g}(\mathrm{n}=10)(\mathrm{p}<0.01)$ in control rats. The mean surface area from 4 control adult rats that was positive for insulin was $1.00 \pm 0.23 \%$ compared with $0.52 \pm 0.05 \%$ in 4 streptozotocin treated animals $(\mathrm{p}<0.05)$.

\section{Differentiation of the Fetal Pancreas}

At the protodifferentiated state of development (14 days of gestation) no difference was observed between control and test groups in total pancreatic DNA or the pancreatic concentration of insulin (Table 3). Similarly, during secondary transition (16-18 days gestation), when there is a dramatic growth of the pancreas and increase in insulin concentration, no significant difference was observed between control and test animals. Only at 20 days was there a significant increase of pancreatic insulin

Table 2. Mean ( \pm SEM) blood glucose of control and streptozotocin-treated rats before and $60 \mathrm{~min}$ after oral glucose $(3.5 \mathrm{~g} / \mathrm{kg})$

\begin{tabular}{|c|c|c|c|c|c|c|c|c|}
\hline & \multicolumn{4}{|c|}{ Control rats } & \multicolumn{4}{|c|}{ Streptozotocin-treated rats } \\
\hline & \multirow[t]{2}{*}{$\mathrm{n}$} & \multirow[t]{2}{*}{$\begin{array}{l}\text { Body weight }{ }^{\mathrm{a}} \\
\text { (g) }\end{array}$} & \multicolumn{2}{|c|}{$\begin{array}{l}\text { Blood glucose } \\
(\mathrm{mmol} / \mathrm{l})\end{array}$} & \multirow[t]{2}{*}{$n$} & \multirow[t]{2}{*}{$\begin{array}{l}\text { Body weight } \\
\text { (g) }\end{array}$} & \multicolumn{2}{|c|}{$\begin{array}{l}\text { Blood glucose } \\
(\mathrm{mmol} / 1)\end{array}$} \\
\hline & & & fasting ${ }^{\mathrm{b}}$ & $60 \mathrm{~min}$ & & & fasting & $60 \mathrm{~min}$ \\
\hline Males & 24 & $280 \pm 5$ & $3.1 \pm 0.09$ & $6.2 \pm 0.15$ & 66 & $232 \pm 7$ & $3.1 \pm 0.08$ & $12.8 \pm 0.29$ \\
\hline Females & 29 & $209 \pm 5$ & $3.3 \pm 0.07$ & $5.4 \pm 0.17$ & 75 & $180 \pm 5$ & $3.4 \pm 0.07$ & $12.4 \pm 0.32$ \\
\hline
\end{tabular}

a Subdivision of the groups by body weight does not alter the results

b Fasting animals sampled at $0730 \mathrm{~h}$ after withdrawal of food at $1600 \mathrm{~h}$ the previous day

Table 3. Effect of parental carbohydrate intolerance on fetal rat pancreatic growth and insulin accumulation (mean \pm SEM)

\begin{tabular}{|c|c|c|c|}
\hline & & Control rats & Streptozotocin-treated rats \\
\hline \multirow{2}{*}{ Day 14} & DNA ( $\mu$ /pancreas) & $1.58 \pm 0.22(5)^{\mathrm{a}}$ & $1.43 \pm 0.09$ \\
\hline & Insulin (ng/ $\mu \mathrm{g}$ DNA) & $0.032 \pm 0.006(5)$ & $0.036 \pm 0.007(7)$ \\
\hline \multirow{2}{*}{ Day 16} & DNA ( $\mu \mathrm{g} /$ pancreas) & $3.38 \pm 0.13 \quad(6)$ & $3.45 \pm 0.22$ \\
\hline & Insulin (ng/ $\mu \mathrm{g}$ DNA) & $0.77 \pm 0.06$ & $0.64 \pm 0.06 \quad(7)$ \\
\hline \multirow{2}{*}{ Day 18} & DNA ( $\mu \mathrm{g} /$ pancreas) & $14.15 \pm 0.47 \quad(10)$ & $12.81 \pm 0.88$ \\
\hline & Insulin (ng/ $\mu \mathrm{g}$ DNA) & $4.68 \pm 0.76 \quad(10)$ & $4.47 \pm 0.38$ \\
\hline \multirow{2}{*}{ Day 20} & DNA ( $\mu \mathrm{g} /$ pancreas) & $22.4 \quad \pm 0.9 \quad(6)$ & $22.2 \pm 1.0$ \\
\hline & Insulin (ng/ug DNA) & $20.8 \pm 1.0$ & $27.8 \pm 1.4 \quad(13)^{\mathrm{b}}$ \\
\hline
\end{tabular}

a Each observation represents one litter pool and the number of observations are shown in parentheses

b Streptozotocin treated compared with control: $p<0.01$ 
concentration in the fetuses of streptozotocin treated parents. There was no difference between control and test animals in overall pancreatic development as measured by DNA.

Two litters born to streptozotocin treated parents were reared and oral glucose tolerance tests were performed at the age of 8 weeks. The mean fasting blood glucose for males and females was $3.0 \pm 0.04$ $\mathrm{mmol} / \mathrm{l}(\mathrm{n}=13)$ and $2.9 \pm 0.06 \mathrm{mmol} / \mathrm{l} \quad(\mathrm{n}=16)$ respectively, and $60 \mathrm{~min}$ after glucose ingestion $6.5 \pm 0.29 \mathrm{mmol} / 1$ and $6.9 \pm 0.27 \mathrm{mmol} / 1$, similar to those observed in control rats (Table 2).

\section{Discussion}

The injection of neonatal rats with a high dose of streptozotocin on the first and second day of life resulted in the survivors developing a mild persistent glucose intolerance. When the same dose of streptozotocin was given on the tenth day of life all the animals died (unpublished observations). These findings suggest that there is a capacity for B cell neogenesis which is limited to the early neonatal period. The insulinopenic model used in the present experiments compares favourably with the model in which a lower dose of streptozotocin $(30 \mathrm{mg} / \mathrm{kg})$ is given intravenously to adult female rats at or just after mating $[6,12]$ since there can be no question of the drug interfering directly with early embryogenesis. When glucose intolerance is induced in pregnant rats with streptozotocin there is an increased percentage of fetal endocrine tissue on day 20 of gestation [6] which agrees well with the present finding of an increased insulin concentration on day 20. Elevated pancreatic insulin concentration was also observed in 20.5 and 21.5 day old fetuses from mildly diabetic females, but not at 19.5 days [7].

The main finding of the present study is the demonstration that the fetal $\mathrm{B}$ cell is only capable of responding to the abnormal intrauterine environment when the pancreas has reached the differentiated state of development. The B cell was unresponsive in the protodifferentiated state, and also during the period of secondary transition, a time of marked growth which interestingly remained unaltered. This conclusion depends on the assumption that pancreatic insulin concentration is a valid marker of fetal $B$ cell sensitivity. If insulin concentration is dependent mainly on the rate of insulin synthesis and largely independent of secretion, it is possible that the metabolic abnormality of diabetic pregnancy affects the fetal B cell some two days earlier, since in the normal rat fetus insulin synthesis peaks on day 18 and the maximum pancreatic insulin concentration occurs on day 20 [13]. The results may indicate fetal autonomy. This would imply that the fetal B cell hyperplasia and hypertrophy characteristic of diabetic pregnancy occurs only when the $\mathrm{B}$ cell becomes competent to release insulin. It would be in keeping with the observation in human diabetic pregnancy that abnormal fetal pancreatic morphology is seen only after 28 weeks gestation [1], which corresponds to the time when the fetal B cell first secretes insulin in response to glucose. The finding that if embryonic rat pancreas is grown in organ culture from day 14 to 20 of gestation amino acids and not glucose cause the growth of more B cells, insulin accumulation, and a precocious development of the glucose secretory response, speaks for the complexity of the adaptive reaction $[14,15]$. The factor or factors responsible for abnormal development of the fetal $\mathrm{B}$ cell in diabetic pregnancy await further elucidation.

The abnormal insulin concentration on day 20 appears to have no adverse effect on later glucose tolerance as judged from two litters. However Aerts and Van Assche [16] have reported that the female offspring of mildly diabetic streptozotocin treated adult female rats develop glucose intolerance during pregnancy and produce fetuses characteristic of a diabetic mother. The concept that gestational diabetes may be an acquired condition awaits further study.

Acknowledgements. We are grateful to Mrs. G. Hostetter and Mr. P. K. Wirdnam for expert technical assistance.

\section{References}

1. Cardell BS (1953) Hypertrophy and hyperplasia of the pancreatic islets in newborn infants. J Pathol 66: 335-346

2. Driscoll SG, Bernirschke K, Curtis GW (1960) Neonatal deaths among infants of diabetic mothers: post-mortem findings in ninety-five infants. Am J Dis Child 100: 818-835

3. Thomas K, de Gasparo M, Hoet JJ (1967) Insulin levels in the umbilical vein and in the umbilical artery of newborns of normal and gestational diabetic mothers. Diabetologia 3: 299-304

4. Van Assche FA, Gepts W (1971) The cytological composition of the fetal endocrine pancreas in normal and pathological conditions. Diabetologia 7: 434-441.

5. Kim JN, Runge W, Wells LJ, Lazarow A (1960) Pancreatic islets and blood sugars in prenatal and postnatal offspring from diabetic rats: beta granulation and glycogen infiltration. Anat Rec 138: 239-260

6. Aerts L, Van Assche FA (1977) Rat foetal endocrine pancreas in experimental diabetes. J Endocrinol $73: 339-346$

7. Kervran A, Guillaume M, Jost A (1978) The endocrine pancreas of the fetus from diabetic pregnant rat. Diabetologia 15: 387-393

8. Herbert V, Lau KS, Gottlieb CW, Bleicher SJ (1965) Coated charcoal immunoassay of insulin. J Clin Endocrinol Metab 25: $1375-1384$ 
9. Burton K (1956) A study of the conditions and mechanism of the dipenylamine reaction for the colorimetric estimation of deoxyribonucleic acid. Biochem J 62: 315-323

10. Sternberger LA (1974) Immunochemistry. Prentice-Hall, Englewood Cliffs, NJ, p 182

11. Weibel ER, Kistler GS, Scherle WF (1966) Practical stereological methods for morphometric cytology. J Cell Biol 30: $23-38$

12. de Gasparo M, de Herdt P, Hoet JJ (1979) Effect of maternal carbohydrate intolerance on the development of the autonomic innervation of the fetal rat pancreas. In: CameriniDavalos RA, Hanover B (eds) Treatment of early diabetes. Plenum Press, New York, p 115-122

13. Pictet R, Rutter WJ (1972) Development of the embyronic endocrine pancreas. In: Greep RO, Astwood EB (eds) Handbook of physiology, Section 7: Endocrinology. American Physiological Society, Washington, p 25-66
14. de Gasparo M, Pictet RL, Rall LB, Rutter WJ (1975) Control of insulin secretion in the developing pancreatic rudiment. Dev Biol 47: 106-122

15. de Gasparo M, Milner GR, Norris P, Milner RDG (1978) Effect of glucose and amino acids on fetal rat pancreatic growth and insulin secretion in vitro. J Endocrinol 77: 241-248

16. Aerts L, Van Assche FA (1979) Is gestational diabetes an acquired condition? J Dev Physiol 1: 219-226

Received: October 26, 1979

and in revised form: March 11, 1980

Dr. M. de Gasparo

Ciba Geigy

$\mathrm{CH}-4002$ Basle

Switzerland 